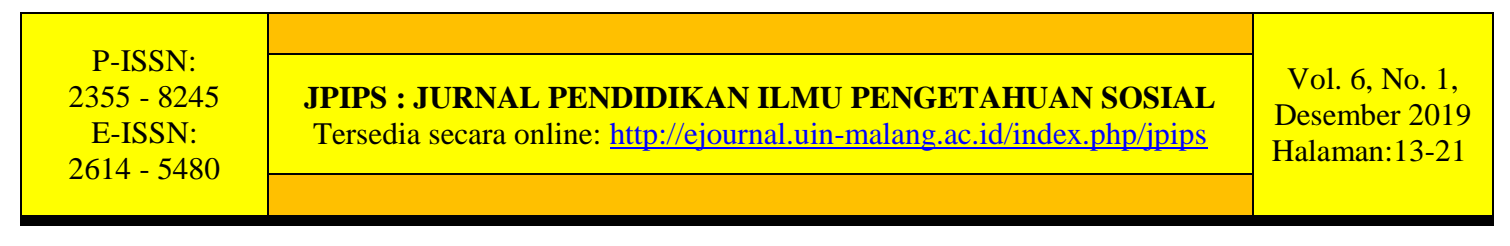

\title{
PENGEMBANGAN INDUSTRI BATIK TULIS SEBAGAI POTENSI DAERAH ( STUDI KASUS DI DESA KLAMPAR KABUPATEN PAMEKASAN)
}

\author{
Sri Ira Suharwati \\ Prodi Tadris Ilmu Pengetahuan Sosial \\ IAIN MADURA \\ sriirasuharwati@gmail.com
}

Diterima:12-10-2019; Direvisi: 14-12-2019; Disetujui: 26-12-2019

Permalink/DOI: 10.18860/jpips.v6i1.7822

\begin{abstract}
Abstrak: Tujuan penelitian adalah untuk mengembangakan industri batik di Desa Klampar sebagai potesni daerah Pamekasan. Desa Klampar merupakan wilayah di Kabupaten Pamekasan yang memiliki jumlah pengarajin batik terbanyak yaitu 1300 orang. Industri batik yang ada di Desa Klampar merupakan industri rumahan yang dilakukan secara turun temurun dan dijadikan sebagai mata pencaharian utama masyarakat. Jenis batik yang sudah dikembangakan yaitu batik tulis dan batik cap. Guna melestarikan batik sebagai potensi dan kebudayaan daerah Pamekasan maka dilakukan berbagai upaya baik oleh pemerintah maupun masyarakat. Dukungan pemerintah yakni: menetapkan Desa Klampar sebagai Kampung batik, pemberian bantuan modal, peningkatan kualitas membatik, perbaikan infrastruktur pasar batik (tradisional dan modern), pemasaran dan promosi. Sedangkan dukungan dari masyarakat berupa pematenan hak cipta motif junjung drajat kontemporer dan daun pacar cina.
\end{abstract}

\section{Kata kunci: Industri Batik, Peran Pemerintah, Peran Masyarakat}

Abstract: The purpose of this study was to develop the batik industry in the Klampar village as a potential area of Pamekasan. Klampar Village is an area in Pamekasan Regency which has the highest number of batik artisans, namely 1300 people. The batik industry in Klampar Village is a home-based industry that has been hereditary and is used as the main livelihood of the community. Types of batik that have been developed are written batik and printed batik. In order to preserve batik as a potential and cultural area of Pamekasan, various efforts have been made both by the government and the community. Government support namely: establishing Klampar Village as a Kampung batik, providing capital assistance, improving the quality of batik, improving the infrastructure of the batik market (traditional and modern), marketing and promotion. While support from the public in the form of patenting copyright junjung drajat motifs and daun pacar cina.

Keywords: Batik Industry, Role of Government, Role of Society 


\section{PENDAHULUAN}

Perkembangan industri saat ini memiliki peran penting dalam kehidupan masyarakat modern. Peran industri sebagai motor penggerak yang memberikan dasar bagi peningkatan dan mobilitas perorangan yang belum pernah terjadi sebelumnya terutama di negara-negara maju. Bagi negara berkembang industri sangat essensial untuk memperluas landasan pembangunan dan memenuhi kebutuhan masyarakat yang terus meningkat (Kristanto, 2002:155).

Sejak UNESCO menetapkan batik sebagai budaya Indonesia pada tanggal 2 Oktober 2009, maka hampir seluruh wilayah di Indonesia mengembangkan industri batik baik industri rumahan maupun industri skala besar. Madura merupakan daerah yang sudah memproduksi batik sejak zaman kerajaan. Motif batik madura memiliki keunikan tersendiri yang tidak dimiliki oleh batik dari daerah lain. Ciri khas batik Madura sebagai usaha rumahan yang mudah dikenali adalah selalu terdapat warna merah dalam motif bunga atau daun.

Industri batik yang ada di Kabupaten Pamekasan merupakan industri skala kecil dan menengah yang tersebar di Kecamatan Proppo, Pegantenan, Palengaan, Galis, Pademawu, dan Pamekasan (Disperindag, 2016). Industri kecil kerajinan batik pada hakekatnya adalah pembangunan suatu sistem yang mempunyai daya hidup dan mampu berkembang secara mandiri serta mengakar pada struktur ekonomi dan masyarakat. Perkembangan industri kecil seperti kerajinan batik tulis akan mendukung program pengentasan kemiskinan khususnya di kabupaten pamekasan. Hal tersebut sesuai dengan peran IKM yaitu upaya pemerintah untuk mengurangi pengangguran, kemisikinan, dan peningkatan pemerataan pendapatan diabandingkan sebagai penggerak ekspor dan sumber investasi wilayah setempat (Tambunan, 2002).

Desa Klampar yang terletak di Kecamatan Proppo Kabupaten Pamekasan menjadi salah satu wilayah yang memiliki jumlah pengrajin batik terbanyak yaitu 1300 orang (monografi desa klampar 2013). Jumlah pengrajin batik yang banyak menjadikan Dusun Banyumas Desa Klampar sebagai kampung batik (Desperindag, 2011). Selain itu, awal mula kerajinan batik mulai dikembangkan oleh masyarakat di Dusun Banyumas, Desa Klampar, yang akhirnya meluas ke seluruh wilayah di Kabupaten Pamekasan.

Kegiatan membatik di Desa Klampar dilakukan secara turun temurun dan dijadikan sebagai pekerjaan sampingan karena masyarakat masih bekerja sebagai petani musiman. Keterampilan membatik tidak melalui semacam kursus atau pelatihan khusus membatik tetapi diwariskan dari generasi ke generasi sampai kemudian mereka mencapai tingkat terampil. Hal tersebut karena dalam membatik membutuhkan pengalaman kurang lebih 1 tahun sehingga menghsilkan batik yang berkualitas tinggi (Fristia \& Navastara, 2014). Motif-motif batik pun telah mengalami perkembangan sesuai dengan lokasinya setelah proses alih profesi yang menjadikan membatik sebagai pekerjaan pokok.

Berdasarkan kondisi industri batik di Desa Klampar dengan mayoritas penduduknya sebagai pembatik menjadikan wilayah tersebut sebagai potensi daerah. Potensi membatik harus dikembangkan karena sebagai penggerak pertumbuhan daerah Pamekasan. Sehingga perlu adanya kerjasama antara pemerintah dan pembatik untuk mengembangkan industri batik rumahan yang ada di Desa Klampar. Sebab, keikutsertaan pemerintah, budayawan, dan masyarakat sendiri dalam melestarikan dan mengembangkan kesenian batik akan mendorong perkembangan industri batik di 
Pamekasan (Tis'aini, 2010). Pengembangan industri batik dapat dilakukan melalui kegiatan ekonomi diantaranya peningkatan pengetahuan dalam hal usaha/produksi.

\section{METODE}

Penelitian ini merupakan deskriptif kualitatif dengan metode pengumpulan data berupa data sekunder yang diperoleh dari Dinas Perdagangan dan Industri Kabupaten Pamekasan, monografi Desa Klampar dan sumber-sumber yang mendukung. Data tersebut kemudian direduksi, disajikan, dan disimpulkan.

\section{HASIL DAN PEMBAHASAN \\ Hasil}

Desa klampar terletak di kecamatan Proppo kabupaten Pamekasan dengan ketinggian tanah 47 dari permukaan laut dan memiliki luas sekitar 274,80 Ha, dimana luas lahan pertanian 215,065 $\mathrm{Ha}$, dan memilki penduduk sebanyak 3078 jiwa (monografi Desa Klampar, 2013). Tata guna lahan di Desa Klampar digunakan sebagai lahan pertanian yang tersebar di Dususn Morsongai, Sumber Papan, Batu Baja, dan Banyumas. Karakteristik tanah di Desa Klampar merupakan tanah marjinal dan berbatu dengan ketersediaan air yang sangat mencukupi sehingga cocok dijadikan sebagai kawasan industri. Berikut sebaran sentra insdutri Batik Tulis di Kabupaten Pamekasan pada tabel 1.

Tabel 1. Sebaran sentra insdutri Batik Tulis di Kabupaten Pamekasan

\begin{tabular}{llcc}
\hline No & \multicolumn{1}{c}{ Desa } & Kecamatan & Jumlah Sentra \\
\hline 1 & Toket & & 10 \\
2 & Candi Burung & Proppo & 7 \\
3 & Klampar & & 24 \\
4 & Pegantenan & Pegantenan & 2 \\
5 & Larangan Badung & & 9 \\
6 & Rek-Kerrek & Palengaan & 3 \\
7 & Rang Perang Daya & & 8 \\
8 & Angsanah & & 4 \\
9 & Banyupelle & Pademawu & 4 \\
10 & Murtajih & Galis & 2 \\
11 & Waru & Pamekasan & 1 \\
12 & Kowel & Kabupaten Pamekasan & 3 \\
\hline
\end{tabular}

Sumber: Dinas Perdagangan dan Industri Kabupaten Pamekasan, 2016

Berdasarkan tabel 1 dapat diketahui bahwa jumlah sentra industri batik kabupaten Pamekasan berada di kecamatan Proppo dengan jumlah total 42 sentra. Sentra insdutri batik di Kecamatan Klampar tersebar di Desa Toket, Candi Burung, dan Klampar dengan jumlah terbanyak yaitu 24 sentra berada di Desa Klampar. Data tersebut menunujukkan bahwa Desa Klampar layak dijadikan sebagai Sentra Industri batik terutama batik tulis.

Berdasarkan eksistensi dan dinamisasi perkembangan batik tulis tersebut, maka secara struktur usaha batik tulis di Desa Klampar ini tergolong ke dalam industri lokal. Dikelompokkan industri lokal karena hasil produksi di desa tersebut pola pemasarannya masih menggantungkan diri kepada pasar lokal ataupun pasar tradisional setempat seperti pasar 17 agustus, pasar palengaan dan pasar kolpajung. Berikut daftar IKM Batik Tulis di Desa Klampar pada tabel 2. 
Tabel 2 Daftar IKM Batik Tulis di Desa Klampar

\begin{tabular}{clcc}
\hline No & \multicolumn{1}{c}{ Nama Pemilik/ Usaha } & Komoditi/ Produk & $\begin{array}{c}\text { Kapasitas Produksi } \\
\text { Potong/ Minggu }\end{array}$ \\
\hline 1 & Batik Tulis "Air Mas" & Batik tulis & 30 lembar \\
2 & Tuplihah & Batik tulis & 100 lembar \\
3 & UD “ANEKA" & Batik tulis & 3000 lembar \\
4 & Aeng Mas & Batik tulis & 200 lembar \\
5 & Maskur & Batik tulis & 200 lembar \\
6 & Sahiruddin & Batik tulis & 40 lembar \\
7 & Moh. Sahiruddin & Batik tulis & 25 lembar \\
8 & Hosniyah & Batik tulis & 50 lembar \\
9 & H. Mannan & Batik tulis & 40 lembar \\
10 & Hamidah & Batik tulis & 25 lembar \\
11 & Bu Su'adah & Batik tulis & 40 lembar \\
12 & Bu Misni & Batik tulis & 10 lembar \\
\hline
\end{tabular}

Sumber: Dinas Perdagangan dan Industri Kabupaten Pamekasan, 2016

Berdasarkan tabel di atas dapat diketahui bahwa Desa Klampar memiliki 12 usaha batik dengan komoditi utamanya adalah batik tulis. Setiap usaha batik memproduksi batik tulis dengan jumlah 10-3000 lembar dalam jangka waktu satu minggu bahkan per setengah bulan. Jumlah produksi yang banyak menunjukkan bahwa batik di Desa Klampar selalu diminati oleh masyarakat sehingga menuntuk pemilik usaha untuk selalu memperoduksinya. Berikut identitas pengrajin IKM Batik di Desa Klampar dapat dilihat pada tabel 3.

Tabel 3. Identitas Pengrajin IKM Batik di Desa Klampar

\begin{tabular}{|c|c|c|c|c|c|c|c|c|}
\hline No & Nama & Pekerjaan & & Produk & No & Nama & Pekerjaan & Produk \\
\hline 1 & Abd Hadi & $\begin{array}{l}\text { Pengrajin } \\
\text { pengusaha }\end{array}$ & $\&$ & $\begin{array}{l}\text { Batik } \\
\text { Caplis }\end{array}$ & 21 & Habidi & pengrajin & \\
\hline 2 & Badwi & $\begin{array}{l}\text { Pengrajin } \\
\text { pengusaha }\end{array}$ & $\&$ & & 22 & Jufri & pengrajin & \\
\hline 3 & Hasbullah & $\begin{array}{l}\text { Pengrajin } \\
\text { pengusaha }\end{array}$ & $\&$ & & 23 & Fauzi & $\begin{array}{l}\text { Pengrajin \& } \\
\text { pengusaha }\end{array}$ & \\
\hline 4 & H Ahmadi & $\begin{array}{l}\text { Pengrajin } \\
\text { pengusaha }\end{array}$ & $\&$ & Batik Cap & 24 & Mas'ud & $\begin{array}{l}\text { pengrajin \& } \\
\text { pengusaha }\end{array}$ & \\
\hline 5 & $\begin{array}{l}\text { K Syamsul } \\
\text { Arifin }\end{array}$ & $\begin{array}{l}\text { Pengrajin } \\
\text { pengusaha }\end{array}$ & $\&$ & & 25 & Yusuf & pengrajin & \\
\hline 6 & Mufrihah & pengrajin & & Batik Cap & 26 & Harun & $\begin{array}{l}\text { Pengrajin \& } \\
\text { pengusaha }\end{array}$ & $\begin{array}{l}\text { Batik } \\
\text { Caplis }\end{array}$ \\
\hline 7 & $\begin{array}{l}\text { Ika } \\
\text { Birahmatin }\end{array}$ & $\begin{array}{l}\text { Pengrajin } \\
\text { pengusaha }\end{array}$ & $\&$ & & 27 & Sirat & $\begin{array}{l}\text { pengrajin \& } \\
\text { pengusaha }\end{array}$ & $\begin{array}{l}\text { Batik } \\
\text { Caplis }\end{array}$ \\
\hline 8 & Muhyi & pengrajin & & & 28 & Abd Aziz & pengrajin & \\
\hline 9 & Wasit & $\begin{array}{l}\text { pengrajin } \\
\text { pengusaha }\end{array}$ & $\&$ & & 29 & Nakah & $\begin{array}{l}\text { pengrajin \& } \\
\text { pengusaha }\end{array}$ & \\
\hline 10 & H Adam Huji & $\begin{array}{l}\text { pengrajin } \\
\text { pengusaha }\end{array}$ & $\&$ & & 30 & Nawi & $\begin{array}{l}\text { pengrajin \& } \\
\text { pengusaha }\end{array}$ & \\
\hline 11 & H Ansori & $\begin{array}{l}\text { pengrajin } \\
\text { pengusaha }\end{array}$ & $\&$ & & 31 & Kit & $\begin{array}{l}\text { pengrajin \& } \\
\text { pengusaha }\end{array}$ & \\
\hline 12 & Bahwi & $\begin{array}{l}\text { pengrajin } \\
\text { pengusaha }\end{array}$ & $\&$ & & 32 & Sunah & pengrajin & \\
\hline 13 & Sahra'i & pengrajin & & & 33 & Hadiyah & $\begin{array}{l}\text { pengrajin \& } \\
\text { pengusaha }\end{array}$ & \\
\hline 14 & Muksin & pengrajin & & Batik Cap & 34 & Huri & $\begin{array}{l}\text { Pengrajin \& } \\
\text { pengusaha }\end{array}$ & \\
\hline 15 & H Rokib & $\begin{array}{l}\text { pengrajin } \\
\text { pengusaha }\end{array}$ & $\&$ & & 35 & Herman & $\begin{array}{l}\text { pengrajin \& } \\
\text { pengusaha }\end{array}$ & \\
\hline
\end{tabular}




\begin{tabular}{|c|c|c|c|c|c|c|c|}
\hline No & Nama & Pekerjaan & Produk & No & Nama & Pekerjaan & Produk \\
\hline 16 & Mahfud & pengrajin & & 36 & Rumiyah & $\begin{array}{l}\text { pengrajin \& } \\
\text { pengusaha }\end{array}$ & \\
\hline 17 & Marsuki & $\begin{array}{l}\text { pengrajin } \\
\text { pengusaha }\end{array}$ & & 37 & Habiyah & $\begin{array}{l}\text { pengrajin \& } \\
\text { pengusaha }\end{array}$ & \\
\hline 18 & Muhammad & pengrajin & & 38 & Ningram & pengrajin & \\
\hline 19 & Nurullah & pengrajin & & 39 & Samsu & pengrajin & \\
\hline 20 & Sihe & pengrajin & & 40 & Tima & pengrajin & \\
\hline
\end{tabular}

Sumber: Dinas Perdagangan dan Industri Kabupaten Pamekasan, 2016

Berdasarkan tabel 2 dapat diketahui bahwa pengusaha batik di Desa Klampar tidak hanya menjual batik tetapi mereka juga bekerja sebagai pengrajin. Produksi batik di Desa Klampar juga sudah mulai bertambah yaitu tidak hanya batik tulis tetapi juga memproduksi batik cap. Semakin beraneka jenis batik menunjukkan bahwa ketertarikan dan dukungan masyarakat untuk melestarikan batik semakin tinggi.

Pengembangan industri batik juga mendapatkan dukungan penuh dari pemerintah, LSM, dan budayawan. Dukungan tersebut yaitu: 1) Penetapan Klampar sebagai kampung batik, 2) bantuan modal, 3) peningkatan kualitas SDM terutam dalam membatik, 4) perbaikan infrastruktur, dan 5) pemasaran dan promosi. Sedangkan peran masyarakat dan pengarajin batik yaitu dengan melakukan pematenan motif batik. Keterlibatan pemerintah dan budayawan menunjukkan bahwa kekayaan budaya berupa membatik menjadi penting untuk dijaga kelestariannya.

\section{Desa Klampar sebagai Sentra Insdustri batik}

\section{Pembahasan}

Industri batik merupakan salah satu sektor industri kreatif dalam sektor kerajinan yang berpotensi memberikan kontribusi baik di bidang sosial, ekonomi, maupun lingkungan. Kontribusi batik dalam bidang ekonomi adalah dijadikan sebagai produk sandang. Penggunaan batik sebagai produk sandang memicu perkembangan industri batik di setiap daerah terutama Madura. Sehingga setiap daerah memiliki ciri dan motif batik yang spesifik sesuai dengan wilayahnya.

Desa Klampar merupakan wilayah sentra industri batik terbanyak di Kabupaten Pamekasan dibandingkan dengan wilayah lain. Hal tersebut terbukti dengan jumlah sentra industri batik di Desa Klampar sebanyak 24 sentra dengan komoditas utama berupa batik tulis (Dinas Perdagangan dan Industri Kabupaten Pamekasan, 2016). Dikategorikan sebagai sentra industri batik karena proses produksi, edukasi, rekreasi, dan ekplorasi hal-hal mengenai batik berada di desa Klampar. Dwinda \& Rahdriawan (2013) menjelaskan bahwa Desa Klampar merupakan desa dengan sentra industri batik tulis terbanyak dimana perkembangannya sangat dipengaruhi oleh aspek kebudayaan.

Potensi suatu daerah menjadi generator pertumbuhan wilayah tersebut. Batik menjadi salah satu hasil kerajinan masyarakat lokal yang dijadikan sebagai potensi daerah Pamekasan. Industri kerajinan batik tulis di Desa Klampar awalnya hanya usaha sampingan saja. Namun, seiring dengan berjalannya waktu kegiatan ini dijadikan sebagai mata pencaharian pokok masyarakat selain bertani sehingga jumlah pengarajin batik mencapai 1300 orang.

Pengembangan industri batik bertujuan agar kekayaan budaya berupa keterampilan membatik sebagai kearifan lokal masyarakat Madura khusunya Kabupaten Pamekasan tetap terjaga kualitasnya. Pelestarian Batik Madura bukan hanya sebagai salah satu warisan (heritage) kekayaan budaya melainkan sebagai sebuah kekuatan merek (branding) akan kualitas dari situs budaya daerah (Rahmawati, 2016). Warisan 
membatik sudah mulai dikembangkan oleh masyarakat Pamekasan terutama Desa Klampar dimana kegiatan tersebut dijadikan sebagai pekerjaan pokok.

Perubahan pekerjaan masyarakat menjadi pembatik menujukkan bahwa ketertarikan akan batik semakin tinggi sehingga industri batik semakin berkembang. Perkembangan industri batik telah mampu memberi lapangan pekerjaan sehingga menambah pendapatan masyarakat yang ada disekitar. Menurut Hasil penelitian Fristia dan Navastara (2014) menjelaskan bahwa keberadaan industri batik Desa Kenongi memberikan kontribusi penurunan jumlah keluarga pra-sejahtera dan peningkatan pendapatan masyarakat.

Industri batik di Desa Klampar pada awal perkembangannya baik pengusaha maupun pembatik hanya mampu menghasilkan jenis batik tulis. Batik tulis dalam prosesnya menggunakan tangan ketika menggambar motif sehingga membutuhkan waktu yang lama. Namun, seiring dengan perkembangan jaman dan tingginya persaingan mengharuskan pembatik agar mampu juga memproduksi batik cap. Sehingga hampir seluruh pengusaha dan pembatik saat ini mampu memproduksi batik tulis dan cap (Dinas Perdagangan dan Industri Kabupaten Pamekasan, 2016).

Pengembangan industri batik di Desa Klampar menjadi program lain pemerintah untuk mengurangi angka kemiskinan. Upaya tersebut sejalan dengan komitmen pemerintah untuk merealisasikan program millennium develop-ment goals (MDGs). Pelaksanaan program tersebut tidak hanya diarahkan untuk meningkatkan pendapatan melainkan juga untuk memberikan akses yang lebih luas bagi seluruh masyarakat agar mampu ke luar dari lingkaran kemiskinan serta lebih berkembang secara mandiri.

\section{Peran Pemerintah dan Masyarakat dalam Mengembangkan Industri Batik sebagai Potensi Daerah Pamekasan}

Pamekasan pada tahun 2009 dikukuhkan sebagai daerah sentra batik di Jawa Timur. Hal tersebut karena Pamekasan mampu menghasilkan kerajinan batik tulis hingga mencapai 1.530 meter sehingga tercatat pada Museum Rekor Indonesia (Muri). Kegiatan membatik semakin berkembang dan menyebar ke seluruh wilayah yang ada di Pamekasan diantaranya di Desa Klampar.

Industri batik di Desa Klampar merupakan industri kecil dan menengah sehingga pengelolaannya secara tradisional. Membatik merupakan kegiatan secara turun temurun dan dapat dikatakan sebagai mata pencaharian masyarakat Desa Klampar. Berdasarkan hal tersebut, maka dukungan pemerintah dalam mengembangkan industri batik sebagai kebudayaan dan potensi daerah diwujudkan dalam beberapa bentuk, yaitu:

1. Menetapkan Desa Klampar, Kecamatan Proppo, sebagai kampung batik. Alasan Desa Klampar dijadikan sebagai Kampung batik karena jumlah pengrajin batik di daerah tersebut paling banyak dibandingakan dengan wilayah lain di Pamekasan,

2. Modal

Bentuk modal yang diberikan oleh ppemerintah berupa bahan baku dan alat produksi. Pemberian bahan baku dan alat produksi bertujuan untuk meningkatkan kuantitas produksi secara berkelanjutan, dan meningkatkan kualitas batik tulis Pamekasan. Pemerintah juga memberikan bantuan pinjaman dana dengan bunga yang rendah. Begitu pula dengan Dinas Koperasi dan UKM memberikan kredit lunak bagi para pengrajin batik untuk keperluan pertambahan modal usahanya. Menurut Bonita (2013) pemberian modal dari Dinas Koperasi dan UMKM Pemerintah akan sangat membantu para pengusaha industri kecil kerajinan batik untuk mengembangkan usahanya. Pemberian Sebab di masa depan hanya industri 
yang memiliki daya saing tinggi yang mampu bertahan dan berkembang mengahadapi persaingan global (Nugrayasa, 2014).

3. Peningkatan kualitas SDM dalam membatik

Peningkatan kualitas SDM tersebut dilakukan melalui pelatihan, pendidikan, dan pendampingan bagi para pengarajin. Salah satu pelatihan yang pernah dilakukan yakni pelatihan pelatihan kepada 35 pengrajin batik di Desa Klampar yang diselenggarakan oleh Dinas Ketenagakerjaan dan Transmigrasi jawa Timur pada januari 2010, dan pelatihan motif batik kontemporer pada tanggal 29 Juni 2010 di Hotel Putri Pamekasan. Hal tersebut merupakan arah pengembangan dan inovasi batik tulis untuk mendukung batik Pemekasan sebagai produk yang berorientasi pada pasar lokal maupun regional. Hasil penelitian Alhusain (2015) menjelaskan bahwa program pelatihan dilakukan untuk menciptakan wirausaha baru dan dengan hasil produsksi yang inovatif sehingga mampu bersaing dengan pasar-pasar yang ada. Hasil penelitian pendukung lain oleh Latifah (2017) menjelaskan bahwa pemerintah Pamekasan mulai melakukan peningkatan desain batik melaui pelatihan dan pendampingan.

4. Perbaikan infrastruktur pasar batik tradisional yang terletak di Pasar 17 Agustus dan membangun pasar batik sejak akhir 2007 di Jalan Jokotole yang dilakukan oleh Dinas perindustrian dan perdagangan (disperindag). Hasil penelitian yang mendukung adalah Sudantoko (2011) menjelaskan bahwa penyediaan rumah dagang usaha kecil dan mengoptimalkan sentra khusus usaha batik merupakan salah satu strategi pemberdayaan usaha batik skala kecil yang berdasarkan akses pasar yang harus diterapkan di Pekalongan.

5. Pemasaran dan promosi; melalui pameran kebudayaan dan industri, kebijakan pemakaian batik, serta penghiasan jalan dan bangunan pemerintahan dengan ornament batik. Hasil penelitian Sudantoko (2011) menjelaskan bahwa informasi dan pameran perdagangan dengan membuat agenda pameran dan membangunan jaringan dengan institusi mitra merupakan salah satu strategi pemberdayaan usaha kecil yang harus diterapkan di Pekalongan. Hasil penelitian Latifah (2017) menjelaskan bahwa strategi pemerintah Pamekasan dalam mengembangakna industri batik juga dalam proses pemasaran melalui promosi batik dan memfasilitasi pemasaran batik. Program lain yang dilakukan pemerintah pada tahun 2011 yaitu mengasah kemampuan para pengusaha batik dalam bentuk pelatihan menggunakan teknologi komputer guna pengembangan pasar batik lebih luas melalui IPTEK.

Selain dukungan pemerintah, masyarakat Desa Klampar juga melakukan beberapa kegiatan guna menjaga kelestarian batik Pamekasan diantaranya yaitu: melakukan pematenan motif batik oleh Abd Rasyid B dan Moh Salam yang diajukan kepada Kementerian Hukum dan Hak Asasi Manusia. Pengajuan hak cipta kedua motif tersebut sudah lama dilakukan namun baru tahun 2019 dipatenkan. Motif batik yang mendapatkan hak cipta adalah motif batik junjung drjat kontemporer dan daun pacar cina. Ide motif batik daun pacar cina tersebut muncul dari dedaunan yang biasa digunakan untuk hias tangan pengantin. Sedangkan motif junjung drajat kontemporer tidak memiliki perubahan yang banyak hanya ada pewarnaan yang lebih cerah sehingga tidak menghilangkan kekhasan aslinya.

Adanya kerja sama yang baik antara masyarakat, LSM dan pemerintah akan mempermudah dalam pengembangan industri batik. Menurut Wahjuni dkk (2014) menjelaskan bahwa terdapat lima pilar yang harus terlibat dalam mengembangkan industri batik, yaitu: pembetik, pemerintah, pengusaha batik, pihak swasta BUMN, dan 
masyarakat. Hasil penelitian Sudantoko (2011) menjelaskan bahwa usaha pengembangan industri batik kecil melalui strategi pemberdayaan yang secara aktif melibatkan LSM dan pemerintah, akademisi, dan pelaku batik. Sehingga tidak hanya industri batik yang berkembang namun dapat meningkatkan kesejahteraan masyarakat sekitar.

\section{KESIMPULAN}

Pengembangan industri batik di Desa Klampar bertujuan untuk menjaga kekayaan budaya dan mengembangkan potensi yang ada di Pamekasan. Potensi membatik salah satu sarana untuk meningkatkan pertumbuhan Pamekasan. Desa Klampar menjadi sasaran pengembangan industri batik karena memilki jumlah pengarajin batik yang lebih banyak dibandingkan wilayah lain. Selain jumlah pengrajin batik yang mencapai 1300 pengrajin wilayah ini juga memiliki 24 sentra industri batik. Hasil produksi desa Klampar berupa batik cap dan tulis dengan komoditas utama yaitu batik tulis. Proses pengembangan industri batik di Desa Klampar di dukung oleh pemerintah, budayawan, pengarajin batik, dan masyarakat. Bentuk dari dukungan pemerintah yaitu: 1) penetapan Klampar sebagai kampung batik, 2) bantuan modal, 3) peningkatan kualitas SDM terutam dalam membatik, 4) perbaikan infrastruktur, dan 5) pemasaran dan promosi. Peran masyarakat dalam mengembangkan potensi membatik yaitu dengan mematenkan motif batik agar menjadi ciri khas Desa Klampar. Koordinaasi yang baik antar masyarakat dan pemerintah mengakibatkan pengembangan industri sebagai potensi daerah berjalan secara maksimal. Manfaat lain yang dirasakan oleh masyarakat dengan adanya pengembangan tersebut yakni dapat mengurangi tingkat pengangguran, memperluas lapangan pekerjaan, dan menambah pendapatan keluarga.

\section{DAFTAR PUSTAKA}

Alhusain, Achmad sani. (2015). Kendala dan Upaya Pengembangan Indutri Batik di Surakakarta Menuju Standardisasi. Jurnal Ekonomi\& Kebijakan Publik. 6 (2), 199-213.

Bonita, F. (2013). Strategi Pengembangan Industri Kecil Kerajinan Batik Di Kota Semarang. Economics Development Analysis Journal, 2(3), 234-245.

Dinas Perdagangan dan Industri Kabupaten Pamekasan. 2016

Dwinda P,E,. \& Rahdriawan, M. (2013). Peran Perempuan Dalam Pengembangan Industri Batik Tulis Di Kabupaten Pamekasan (Studi Kasus Di Desa Klampar, Kecamatan Proppo, Kabupaten Pamekasan). Disertasi. Universitas Diponegoro.

Fristia, V. F., \& Navastara, A. M. (2014). Faktor penyebab belum berkembangnya industri kecil batik Desa Kenongo Kecamatan Tulangan-Sidoarjo. Jurnal Teknik ITS, 3(2), C190-C195.

Kristanto, Philip. (2002). Ekologi Industri. Yogyakarta: Andi

Latifah, D. (2017). Strategi Pemerintah Daerah dalam Pengembangan Industri Batik Pamekasan (Studi Pada Dinas Perindustrian dan Perdagangan Kabupaten Pamekasan). Disertasi. Universitas Brawijaya.

Monografi Desa Klampar. 2013.

Nugrayasa, O. (2014). Ketika Produk Impor membanjiri Pasar Indonesia. [Online] Diambil dari http://setkab.go.id/arikel-11655-html.

Sudantoko, D. (2012). Strategi Pemberdayaan Usaha Skala Kecil Batik Di Pekalongan. Eksplanasi, 6(1), 29-45 
Tambunan, Tulus. (2001). Industrialisasi di Negara Sedang Berkembang, Kasus Indonesia. Jakarta: Ghalia Indonesia.

Tis'aini, N. (2010). Analisis Faktor-Faktor yang Mempengaruhi Perkembangan Industri Batik Madura di Pamekasan (Studi Kasus Pada Industri Batik di Dusun Banyumas, Desa Klampar, Kecamatan Proppo, Kabupaten Pamekasan). Skripsi Jurusan Ekonomi Pembangunan-Fakultas Ekonomi UM.

Wahjuni, S., Suryawati, D., \& Yulisda Dwi, H. (2014). Model Inovasi Motif dan Produk Dalam Membangun Sentra Indutri Batik Berbasis Kreativitas Pada Pengrajin Batik Gedhog di Kabupaten Tuban. 